Jurnal Konstruksi Hukum | ISSN: XXXX | E-ISSN: XXXX Vol. 1, No. 1, September 2020 Hal. 170-175| Available online at https://www.ejournal.warmadewa.ac.id/index.php/jukonhum DOI: https://doi.org/10.22225/jkh.1.1.2151.170-175

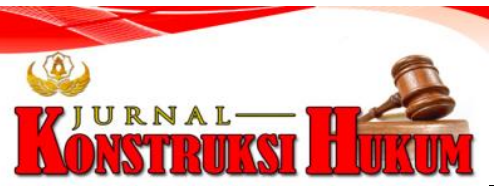

\title{
PENERAPAN SANKSI ADAT KASEPEKANGDI DESA ADAT TANJUNG BENOA KECAMATAN KUTA SELATAN KABUPATEN BADUNG
}

\author{
I Gede Yoga Paramartha Duarsa, I Nyoman Gede Sugiartha Diah Gayatri Sudibya \\ Fakultas Hukum Universitas Warmadewa, Denpasar, Bali - Indonesia
}

\begin{abstract}
Abstrak
Adat dan kebiasaan masyarakat Hindu di Bali pada hakikatnya dibina, dipelihara, serta dipimpin oleh lembaga yang dinamakan Desa Adat yakni suatu desa yang berbeda posisi serta fungsi dengan desa dinas (desa administratif pemerintahan). Adapun peraturan di Desa Adat Bali yang tidak boleh dilanggar. Apabila kedapatan pelanggaran, maka akan diberi salah satu sanksi yakni Kasepekang. Kasepekang merupakan sanksi adat Bali, dimana si penerima sanksi akan dikucilkan, diasingkan atau diberhentikan dari kegiatan di desa (Madesa). Hal ini dikarenakan si pelaku melanggar aturan desa adat berkali-kali (keterlaluan), sehingga sanksi ini dianggap pantas untuk diberikan. Bila seorang atau kelompok anggota desa dianggap melanggar norma-norma hukum di sebut dengan "awig-awig" dalam bahasa adat Bali. Penelitian ini bertujuan untuk mengetahui penerapan sanksi adat serta hambatan-hambatan dalam penerapan sanksi adat di Desa Adat Tanjung Benoa Kecamatan Kuta Selatan Kabupaten Badung. Metode penelitian ini menggunakan metode empiris yang berpedoman pada teknik pengumpulan data dengan wawancara langsung kepada yang berkompeten dengan menggunakan teori receptie, teori receptio in complexu dalam konsep negara hukum untuk mengkaji fenomena yang terjadi saat ini dalam ketertiban kehidupan masyarakat Desa Adat Tanjung Benoa yang didasari pada Peraturan Daerah Bali Nomor 4 Tahun 2019 tentang Desa Adat. Hasil penelitian menunjukkan bahwa penerapan sanksi adat kasepekang di Desa Adat Tanjung Benoa dilaksanakan oleh pimpinan adat yaitu Kelihan Banjar atau Kelihan Adat dengan bebarapa tahapan berupa memberikan petuah (pitutur ayu), memberikan teguran (penglemek) sampai pada disisihkan (Kasepekang) dari kegiatan organisasi sosial masyarakat banjar. Hal ini diharapkan agar warga menjadi sadar dan mengikuti apa yang menjadi kesepakatan masyarakat Banjar Adat.
\end{abstract}

Kata Kunci: Desa adat; Kasepekang; Sanksi adat

\begin{abstract}
The customs and habits of the Hindu community in Bali are basically fostered, maintained, and led by an institution called Desa Adat, which is a village with a different position and function from the official village (government administrative village). There are regulations in the Balinese Traditional Village that must not be violated. If a violation is found, it will be given one of the sanctions, namely Kasepekang. Kasepekang is a Balinese customary sanction, where the recipient of the sanction will be excommunicated, exiled or terminated from activities in the village (Madesa). This is because the perpetrator has repeatedly violated the rules of the traditional village (outrageous), so that this sanction is deemed appropriate. If a person or group of village members is deemed to have violated legal norms, it is called "awig-awig" in the Balinese traditional language. This study aims to determine the application of customary sanctions as well as obstacles in the application of customary sanctions in the Tanjung Benoa Traditional Village, South Kuta District, Badung Regency. This research method uses an empirical method that is guided by data collection techniques by direct interviews with those who are competent using the receptio theory, the theory of receptio in complexu in the concept of a rule of law to examine the current phenomenon in the orderliness of the life of the Tanjung Benoa Traditional Village community which is based on regulations. Bali Region Number 4 of 2019 concerning Traditional Village. The results showed that the implementation of the Kasepekang customary sanctions in the Tanjung Benoa Traditional Village was carried out by the traditional leaders, namely Kelihan Banjar or Kelihan Adat with several stages in the form of giving advice (pitutur ayu), giving a warning (penglemek) to being excluded (Kasepekang) from the activities of community social organizations. banjar. It is hoped that people will become aware of and follow what the Banjar Adat community has agreed to do.
\end{abstract}

Keywords: Traditional village; Kasepekang; Adat sanctions 


\section{PENDAHULUAN}

Negara Indonesia merupakan sebuah negara yang berkembang dengan kata lain sedang atau tengah mencari bentuk terbaik serta ideal bagi seluruh komponen bangsa dan Negara dalam cita-cita menjadi negara maju dalam segala bidang, namun tanpa melepaskan budaya, adat, kearifan lokal demi tujuan untuk meningkatkan kesejahteraan masyarakat. Untuk mencapai keberhasilan tersebut tentunya diperlukan suatu sistem atau sesuatu untuk mengatur dan yang paling dasar dari sesuatu tersebut adalah Hukum. Bali merupakan daerah yang memiliki aneka ragam adat, budaya serta kebiasaan di setiap wilayahnya atau desanya termasuk peraturan di setiap desa khususnya desa pakraman atau desa adat yang cenderung berbeda dibandingkan desa lainnya, hal ini juga membentuk sebuah sistem peraturan di sebuah desa berbeda bahkan jika di lihat peraturan tersebut bisa di bagi menjadi 2 (dua) tipe peraturan, yaitu peraturan di desa dinas dan desa pakraman atau desa adat yang secara tugas kepemerintahan sangat berbeda fungsi, tugas dan tanggung jawabnya (Ketut Arya Sunu et al., 2015; Putri et al., 2019).

Adat serta kebiasaan masyarakat Hindu di Bali dipelihara, dibina, dan dipimpin oleh suatu lembaga yang dinamakan Desa Adat yakni suatu desa yang berbeda status, kedudukan, dan fungsinya dengan desa dinas (desa administratif pemerintahan), baik ditinjau dari segi pemerintahan maupun dari sudut pandang masyarakat (Dewi, 2016). Dengan penjelasan bahwa Desa Adat ialah desa yang dilihat fungsinya di bidang adat (desa yang hidup secara tradisional sebagai perwujudan dari lembaga adat), sedangkan Desa Dinas ialah desa yang dilihat fungsinya di bidang pemerintahan merupakan lembaga pemerintahan yang paling terbawah dalam rangka pelaksanaan otonomi daerah.

Peraturan Daerah Bali Nomor 4 Tahun 2019 tentang Desa Adat yang dalam definisinya adalah kesatuan masyarakat hukum adat di Provinsi Bali yang mempunyai satu kesatuan tradisi serta tata krama pergaulan hidup masyarakat umat hindu secara turun temurun dalam ikatan khayangan tiga atau khayangan desa yang mempunyai wilayah tertentu serta harta kekayaan sendiri dan berhak mengurus rumah tangganya sendiri. Secara umum dapat dibedakan dengan desa dinas yang definisinya bahwa desa dinas mengatur hukum sesuai dengan hukum pemerintahan nasional yang secara hirarki kepemerintahan merupakan struktur pemerintah pusat terbawah yang bertugas di suatu wilayah kelurahan atau desa dinas, sedangkan desa adat atau desa pakraman mengatur hukum sesuai dengan hukum di desa pakraman (hanya khusus di wilayah desa tersebut). Peraturan-peraturan desa adat di Bali begitu beragam serta berbeda antara desa satu dengan desa lainnya, sehingga banyak terdapat peraturan adat yang ada di Bali (Muin \& Mucharom, 2016). Peraturan-peraturan tersebut menyangkut aturan tentang kelahiran, kehidupan, sampai kematian serta juga tentang hubungan manusia dengan tuhan (Parahyangan), hubungan manusia dengan alam atau lingkungan (Palemahan) dan hubungan manusia dengan manusia itu sendiri (Pawongan).

Awig - awig merupakan aturan yang dibuat oleh krama desa / Banjar Pakraman yang dipakai sebagai pedoman dalam melaksanakan Tri Hita Karana sesuai dengan Desa Mawacara dan Dharma Agama(A.A. Putu Wiwik Sugiantari \& Julianti, 2019; Made Adi Widnyana \& Putu Tagel, 2019). Awig - awig atau yang biasa disebut peraturan desa adat tersebut memuat tentang aturan penduduk desa (krama desa) yang dapat dikatagorikan menjadi 3 (tiga) yaitu: penduduk adat asli (krama adat), penduduk pendatang yang beragama Hindu (krama tamiu) dan penduduk pendatang yang beragama non hindu (tamiu). Penduduk adat asli di dijabarkan penduduk yang memang menetap secara turun temurun di desa adat, beragama hindu serta telah memiliki tempat tinggal yang merupakan penduduk pokok yang bertanggung jawab dengan kegiatan-kegiatan adat yang dilakukan di desa adat (Larantika, 2017). Sedangkan penduduk lainnya seperti krama tamiu dan tamiu mempunyai tanggung jawab seperti yang di atur dalam peraturan adat desa adat atau awig-awig. Setiap aturan tidak terkecuali dengan awig-awig dan perarem akan memiliki sanksi sebagai tindakan untuk memberi efek jera kepada setiap orang yang diatur di dalam masyarakat desa adat. Salah satu keunikan aturan desa adat atau desa pakraman di Bali yakni adanya sanksi adat yang bersifat lembut sebagai teguran dan sampai yang cukup keras bagi masyarakat adat yang melakukan kesalahan atau pelanggaran aturan desa adat di wilayah tersebut (Kristiono, 2017).

Salah satu sanksi adat yang cukup keras adalah Kasepekang dimana si penerima sanksi akan dikucilkan, diasingkan atau diberhentikan untuk ikut di desa (Madesa). Hal ini dikarenakan si pelaku sanksi melanggar aturan desa adat berkali-kali (keterlaluan), sehingga sanksi ini dianggap pantas untuk diberikan. Selain itu seorang atau kelompok anggota desa yang dianggap melanggar 
norma- norma hukum yang dalam bahasa adat Bali di sebut dengan "awig-awig" yang berlaku di desa tersebut, dengan sanksi dikucilkan dari desa adat setempat, dilarang tinggal di wilayah tersebut, tidak boleh menggunakan fasilitas adat berupa kuburan dan tempat suci (Pura) dan juga dilarang berkomunikasi atau bersosialisasi dengan masyarakat atau anggota desa adat lainnya. Krama desa adat juga dilarang berbicara kepada orang yang sedang kasepekang, tak boleh menolong orang atau kelompok itu, dan orang atau kelompok yang sedang menjalani hukuman kasepekang tidak mendapatkan pelayanan apa pun dari adat. Bahkan orang atau kelompok yang kasepekang dilarang ke pura milik desa adat untuk bersembahyang. Hukum kasepekang hanya untuk krama Bali di wilayah adat tertentu yang beragama Hindu, untuk itu selain krama Bali yang diantaranya adalah para pendatang atau agama lain tidak terkena hukum kasepekang atau hukum adat itu (Gede Yoga Satriya Wibawa \& Wiradnyana, 2019). Seperti hal nya yang terjadi pada tahun 2018 dimana seorang kepala keluarga yang bernama I Nyoman Darna beserta keluarga mendapatkan sanksi adat berupa kasepekang karena dianggap melanggar kesepakatan masyarakat dengan menggugat tanah yang telah disertifikatkan oleh Desa Adat sehingga terjadi perbedaan pendapat dengan masyarakat, sehingga dikenakan atau di jatuhi sanksi adat berupa kasepekang.

Adapun tujuan pelaksanaan penelitian ini, yakni untuk mengetahui penerapan sanksi adat hambatan-hambatan dalam penerapan sanksi adat di Desa Adat Tanjung Benoa Kecamatan Kuta Selatan Kabupaten Badung.

\section{METODE PENELITIAN}

Penelitian ini menggunakan jenis penelitian empiris, dimana penelitian empiris merupakan suatu proses untuk menemukan aturan hukum atau bekerjanya hukum dalam masyarakat, prinsip-prinsip hukum maupun pendapat- pendapat hukum yang mana penelitian tempat terjadinya suatu permasalahan merupakan dasar dari kegiatan penelitian untuk mendapatkan jawaban dari permasalahan hukum yang dihadapi yang tentu saja berfokus pada perilaku masyarakat hukum (law in action) dimana memerlukan tambahan data data sekunder yang berupa bahan atau referensi hukum lainnya sebagai data penunjang dari penelitian lapangan yang penulis lakukan. (Arliman S, 2018)

Data dan sumber data yang di pakai dalam penelitian ini meliputi bahan hukum seperti: Data primer adalah data dari sumber pertama secara langsung di tempat penelitian yaitu di Desa Adat Tanjung Benoa mengenai berjalan atau tidaknya fungsi hukum adat dalam kaitannya dengan hukum positif suatu negara di tengah - tengah masyarakat adat, dimana wawancara dilakukan langsung dengan masyarakat seperti Wawancara langsung dengan Bandesa Adat Tanjung Benoa, Wawancara langsung dengan Kelihan Adat Banjar Kertha Pascima Desa Adat Tanjung Benoa, dan Wawancara langsung dengan tokoh serta pelaku dari masyarakat Desa Adat Tanjung Benoa. Berikutnya, Data sekunder merupakan data atau bahan hukum yang diperoleh dari berbagai literatur dan peraturan perundang-undangan serta pendapat beberapa penlitian terdahulu yang relevan dengan judul penelitian ini. Bahan hukum sekunder yang penulis gunakan di dalam tulisan ini yakni: Undang - Undang Dasar Negara Republik Indonesia Tahun 1945, Undang - Undang Nomor 39 tahun 1999 Tentang Hak Asasi Manusia Peraturan Daerah Provinsi Bali Nomor 3 tahun 2003 tentang Perubahan Peraturan Daerah Provinsi Bali Nomor 3 Tahun 2001 tentang Desa Pakraman, termasuk juga Awig-Awig Desa Adat Tanjung Benoa serta Perarem Desa Adat Tanjung Benoa. Sumber data selanjutnya, bahan hukum tersier atau bahan hukum penunjang yang memberikan petunjuk terhadap bahan hukum primer dan sekunder dan terdiri dari Kamus dan Literatur tentang hukum adat.

Teknik pengumpulan data yang digunakan dalam penelitian ini adalah Teknik wawancara atau interview yang lazim digunakan dalam penelitian empiris. Dimana wawancara dilakukan dengan memberikan pertanyaan yang telah di rancang dengan sistematis untuk memperoleh jawaban yang relevan dengan permasalahan yang ada dalam penelitian ini.

Teknik analisis bahan hukum yang digunakan adalah Teknik dasar analisis yang mendeskripsikan atau menggambarkan uraian terhadap kondisi proposisi-proposisi hukum dan non hukum yang membentuk konstruksi yuridis dengan melakukan analogi, pembalikan dan tanggung jawab serta dampak dari permasalahan yang ada. Selain itu, telah dilakukan juga penilaian atau evaluasi berupa tepat atau tidak tepat, setuju atau tidak setuju dan syah atau tidak syah dari penelitian 
tentang pandangan rumusan norma hukum yang terdapat pada bahan hukum primer dan bahan hukum sekunder.

\section{HASIL DAN PEMBAHASAN}

\section{Penerapan Sanksi Adat di Desa Adat Tanjung Benoa}

Di Indonesia aturan-aturan tentang segi kehidupan manusia tersebut menjadi aturan-aturan hukum yang mengikat yang disebut hukum adat. Hukum Adat pada umumnya belum atau tidak tertulis yaitu kompleks norma-norma yang bersumber pada perasaan keadilan rakyat yang selalu berkembang meliputi peraturan tingkah laku manusia dalam kehidupan sehari-hari, senantiasa ditaati dan dihormati karena mempunyai akibat hukum atau sanksi. Dari definisi di atas, dapat disimpulkan bahwa Hukum Adat merupakan sebuah aturan yang tidak tertulis dan tidak dikodifikasikan, namun tetap ditaati dalam masyarakat karena mempunyai suatu sanksi tertentu bila tidak ditaati. Diakui atau tidak, namun Hukum Adat juga mempunyai peran dalam Sistem Hukum Nasional di Indonesia. Dalam Undang-Undang Dasar Republik Indonesia pasal 18 B Ayat 2 yang menyatakan bahwa "Negara mengakui serta menghormati kesatuan-kesatuan masyarakat hukum adat beserta hak-hak tradisionalnya sepanjang masih hidup dan sesuai dengan prinsip Negara Kesatuan Republik Indonesia". Timbulnya Sanksi Adat karena adanya Hukum Adat, dan kedudukan Hukum Adat menurut ketentuan hukum positif di Indonesia yang dijamin dalam pasal 18 B Ayat 2 UndangUndang Dasar Republik Indonesia tahun 1945. Maka dari itu, secara otomatis kedudukan Sanksi Adat menurut ketentuan Hukum Positif di Indonesia juga terjamin di dalam pasal 18 B Ayat 2 UndangUndang Dasar Republik Indonesia Tahun 1945.

Tahapan dari penerapan dan penjatuhan sanksi kasepekang di Desa Adat Tanjung Benoa, Kabupaten Badung yang dipaparkan oleh Bandesa Adat Tanjung Benoa meliputi warga tersebut berdasarkan paruman/ sangkepan (rapat krama banjar) dinyatakan bersalah kemudian warga tersebut dipanggil melalui Surat untuk hadir dalam paruman/sangkepan (Pembinaan I), seterusnya jika tidak menemui hasil atau warga tersebut tidak hadir, maka akan kembali dipanggil untuk ikut paruman/ sangkepan lagi diundang dengan surat (Pembinaan II). Apabila tidak menemui kesepakatan atau warga tersebut tidak hadir lagi maka dilakukan pemanggilan terakhir untuk ikut paruman/ sangkepan dan diundang dengan Surat (Pembinaan III). Jika memang dengan cara pembinaan itu warga tersebut masih belum bisa diterima oleh warga lainnya atau ia tidak mau menghadiri paruman/sangkepan tersebut, maka baru akan dijatuhkan sanksi kasepekang.

Penerapan sanksi awig - awig Desa Adat Tanjung Benoa, Kecamatan Kuta Selatan di laksanakan berdasarkan beberapa tahapan yakni SAMA: Marupa Pitutur Ayu Artinya saat ada kesalahan yang diakukan oleh warga masyarakat akan di berikan teguran untuk kebaikan.tahapan selanjutnya BEDA: Kedukain panglemek, Kecepikang artinya setelah teguran - teguran itu tidak diindahkan akan dilakukan pemanggilan dengan memberikan ultimatum untuk di sisihkan dari aktivitas sosial di masyarakat banjar. Selanjutnya, DANA: Pamidana marupa Jinah setelah teguran dan ultimatum dapat dilaksanakan, maka akan diberikan sanksi pembayaran berupa uang denda yang di sepakati oleh warga masyarakat. Yang terakhir DANDA: Marupa pangupakara merayascita artinya setelah masyarakat yang membuat kesalahan tersebut mau mengikuti keputusan masyarakat tersebut maka di berikan sanksi untuk membuat upacara sebagai saksi kepada tuhan bahwa si pelanggar tersebut telah sadar dari apa yang di lakukan dan menjadi satu dengan masyarakat lainnya.

Perlu perbaikan terhadap ketidakseimbangan, perbaikan ini juga dilaksanakan secara skala dan niskala. Pelanggaran terhadap awig-awig banjar atau Desa Adat, yang berwenang menyelesaikan suatu kasus atau masalah di Desa Adat Tanjung Benoa, Kecamatan Kuta Selatan yaitu Prajuru Adat beserta perangkat Desa Adat yang dibantu oleh Kelihan Banjar. Desa adat lahir karena adanya kepentingan orang-orang yang mengikatkan dirinya ke dalam satu ikatan kelompok yang memiliki sifat teritorial serta memudahkannya tercapai berbagai kebutuhan hidup, baik yang bersifat teritorial serta lahiriah maupun batiniah. Selain desa adat tersebut terbentuk atas kepentingan warganya, Struktur organisasi maupun peraturan-peraturan (awig-awig) yang berkembang bagi krama desa dapat menjadi sebuah alasan bahwa penerapan sanksi terhadap pelanggaran yang dilakukan oleh krama desa tidak terlepas dari itu semua. Secara harafiah hukum, Hukuman atau sanksi adat yang diterima oleh seseorang atau sekelompok orang yang melanggar norma-norma atau awig awig yang berlaku di banjar atau desa adat, dengan cara pengucilan dikucilkan dari banjar/ desa adat 
setempat, dilarang tinggal di wilayah tersebut, tidak boleh menggunakan fasilitas kuburan serta juga dilarang berkomunikasi atau bersosialisasi dengan anggota banjar lainnya yaitu disebut kasepekang, Bahkan orang atau kelompok yang kasepekang dilarang ke pura untuk bersembahyang.

Aturan desa adat yang berupa perarem merupakan keputusan masyararakat yang terkadang berdasarkan jumlah suara terbanyak, dan pada saat kepentingan pragmatis tertentu opini masyarakat menjadi sangat berbeda dengan hak seseorang untuk mencari keadilan dalam ranah hukum positif. Untuk itulah sering menimbulkan konflik yang berujung pada seseorang atau warga masyarakat terkena sanksi adat kasepekang ini. Walaupun secara kasat mata keputusan adat berupa perarem banyak berdasarkan pada sorakan opini kepentingan tertentu (suryak siu) yang tidak menggunakan logika hukum positif untuk memutuskan suatu permasalahan.

\section{Hambatan-Hambatan Penerapan Sanksi Adat di Desa Adat Tanjung Benoa}

Upaya-upaya yang dilakukan dalam meminimalisir hambatan-hambatan penerapan sanksi adat kasepekang di Desa Adat Tanjung Benoa, Kecamatan Kuta Selatan, Kabupaten Badung dilakukan dengan beberapa cara, yakni: mengupayakan adanya mediasi dan pendekatan-pendekatan sebelum permasalahan meruncing untuk mendapatkan solusi terbaik dalam lingkup perdamaian secara kekeluargaan dengan prinsip segilik, seguluk, sebayan antaka. Kemudian menerapkan tahapan-tahapan aturan pengenaan sanksi yang telah diatur dalam awig-awig Desa Adat Tanjung Benoa, Kecamatan Kuta Selatan, Kabupaten Badung yang telah disepakati bersama-sama oleh semua masyarakat dengan arif dan bijaksana. Selanjutnya, mengadakan rapat atau paruman prajuru Desa Adat atau pengurus Desa Adat untuk menentukan langkah-langkah yang patut diambil dalam menyikapi permasalahan yang ada. Hal ini diperlukan untuk menyatukan persepsi untuk melakukan tindakan-tindakan yang tepat. Yang terakhir adalah mengadakan rapat-rapat prajuru desa adat dengan ahli-ahli hukum termasuk dengan Majelis Desa Adat yang ada untuk mendapatkan masukan tentang tindakan yang dilakukan dalam setiap permasalahan.

\section{SIMPULAN DAN SARAN}

\section{Simpulan}

Penerapan sanksi adat kasepekang di Desa Adat Tanjung Benoa Kecamatan Kuta Selatan Kabupaten Badung dilaksanakan oleh pimpinan adat yaitu Kelihan Banjar atau Kelihan Adat dengan tahapantahapan berupa memberikan petuah (pitutur ayu), memberikan teguran-teguran (penglemek) sampai pada disisihkan (Kasepekang) dari kegiatan organisasi sosial masyarakat adat. Hal ini diharapkan agar warga menjadi sadar dan mengikuti apa yang menjadi kesepakatan masyarakat adat. Kemudian, hambatan penerapan sanksi ada kasepekang di Desa Adat Tanjung Benoa Kecamatan Kuta Selatan Kabupaten Badung yaitu: dasar aturan awig - awig yang di gunakan adalah awig - awig tahun 1985 dimana sudah tidak relevan dengan situasi saat ini dan yang wajib mempertimbangkan hak asasi manusia. Adanya perbedaan pandangan hukum antara prajuru banjar adat dengan Prajuru desa adat (perangkat desa) yang terkadang menyebabkan terjadinya perbedaan pandangan yang sangat perlu pembinaan oleh pemerintah daerah.

\section{Saran}

Berdasarkan hasil penelitian, disarankan kepada pimpinan adat atau prajuru banjar agar peraturan adat atau awig-awig sebisa mungkin di perbaharui dengan pembuatan perarem- perarem yang sesuai dengan perkembangan jaman dan mempertimbangkan hak asasi manusia serta dilakukan pelatihan-pelatihan tentang penerapan hukum bagi prajuru atau pimpinan adat, agar dapat memberikan pencerahan kepada masyarakat serta dapat memberi pertimbangan tentang keadilan putusan yang berkaitan dengan sanksi adat. Kemudian disarankan kepada seluruh masyarakat Desa Adat agar selalu memperhatikan dan mentaati aturan yang ada, baik aturan yang ada di dalam hukum positif ataupun aturan yang ada di dalam hukum adat agar tidak terjadinya pelanggaran-pelanggaran hukum yang akan membuat kerugian. 


\section{DAFTAR PUSTAKA}

A.A. Putu Wiwik Sugiantari, \& Julianti, L. (2019). Peranan Awig-Awig Desa Pakraman dalam Mencegah Tindak Pidana Pencurian Benda Sakral di Desa Pelaga Kecamatan Petang Kabupaten Badung. Jurnal Bakti Saraswati, 53(9), 1689-1699.

Arliman S, L. (2018). Peranan Metodologi Penelitian Hukum di dalam Perkembangan Ilmu Hukum di Indonesia. Soumatera Law Review, 1(1), 112-132.

Dewi, N. M. L. L. K. (2016). Peran Desa Pakraman dalam Pembentukan Perarem Terkait Penyelesaian Konflik Alih Fungsi Lahan (Studi Kasus di Desa Pakraman Tunjuk, Kabupaten Tabanan). Jurnal Magister Hukum Udayana, 5(3), 435-446.

Gede Yoga Satriya Wibawa, \& Wiradnyana, I. G. A. (2019). Implementasi Hukum Adat dengan Sanksi Kasepekang Ditinjau dari Perspektif Hak Asasi Manusia. Pariksa - Jurnal Hukum Agama Hindu STAHN Mpu Kuturan Singaraja, 53(9), 40-50.

Ketut Arya Sunu, I. G., Sanjaya, D. B., \& Sugiartha, W. (2015). Harmonisasi, Integrasi Desa Pakraman dengan Desa Dinas yang Multietnik dan Multiagama Menghadapi Pergeseran, Pelestarian, dan Konflik di Bali. Jurnal Ilmu Sosial Dan Humaniora, 3(2), 446-458.

Kristiono, N. (2017). Pola Kehidupan Masyarakat Adat Desa Tenganan Pegringsingan Bali. Integralistik, 28(2), 158-175.

Larantika, A. A. A. D. (2017). Kata kunci: desa adat, penertiban penduduk pendatang. Jurnal Dialektika, 2(1), 167-177.

Made Adi Widnyana, I., \& Putu Tagel, D. (2019). Penerapan Sanksi Adat Dedosan dalam Awig-Awig Banjar Pegok Desa Adat Sesetan. Vyavahara Duta, XIV(2), 32-36.

Muin, F., \& Mucharom, R. S. (2016). Desa dan Hukum Adat: Persepektif Normativitas dan Sosiologis Keindonesiaan. Prosiding Seminar Nasional Multi Disiplin Ilmu \& Call for Paper UNISBANK $K E-2,1(6), 461-468$.

Putri, K. A. M. P., Puspitasari, N. W. F., Dewi, N. K. K., Ekarini, N. W., Dewi, I. A. P. P., \& Mertadana, D. P. K. (2019). Pengaruh Hukum Adat Atau Awig-Awig terhadap Pengelolaan Dana Desa di Desa Banjar Kecamatan Banjar Kabupaten Buleleng Provinsi Bali. Jurnal Ilmiah Akuntansi Dan Humanika, 8(1), 1-13. 